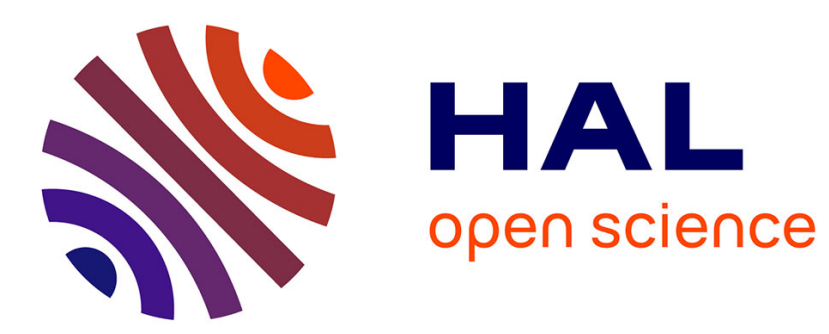

\title{
Systems modelling and the development of coherent understanding of cell biology
}

Roald Pieter Verhoeff, Kerst Th. Boersma, Arend Jan Waarlo

\section{To cite this version:}

Roald Pieter Verhoeff, Kerst Th. Boersma, Arend Jan Waarlo. Systems modelling and the development of coherent understanding of cell biology. International Journal of Science Education, 2008, 30 (04), pp.543-568. 10.1080/09500690701237780 . hal-00513340

\section{HAL Id: hal-00513340 \\ https://hal.science/hal-00513340}

Submitted on 1 Sep 2010

HAL is a multi-disciplinary open access archive for the deposit and dissemination of scientific research documents, whether they are published or not. The documents may come from teaching and research institutions in France or abroad, or from public or private research centers.
L'archive ouverte pluridisciplinaire HAL, est destinée au dépôt et à la diffusion de documents scientifiques de niveau recherche, publiés ou non, émanant des établissements d'enseignement et de recherche français ou étrangers, des laboratoires publics ou privés. 


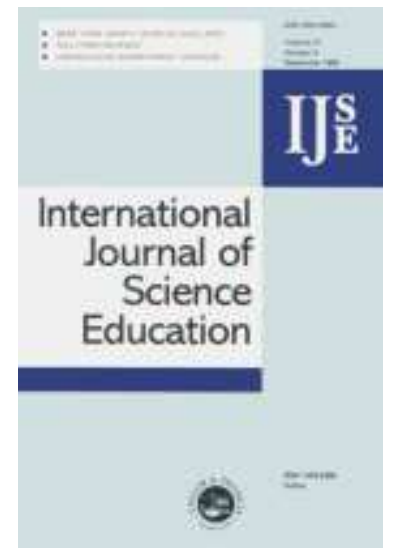

\section{Systems modelling and the development of coherent understanding of cell biology}

\begin{tabular}{|r|l|}
\hline Journal: & International Journal of Science Education \\
\hline Manuscript ID: & TSED-2006-0157.R2 \\
\hline Manuscript Type: & Research Paper \\
\hline Keywords: & $\begin{array}{l}\text { developmental research, secondary school, biology education, } \\
\text { learning activities, qualitative research }\end{array}$ \\
\hline Keywords (user): & systems modelling, cell biology, learning and teaching strategy \\
\hline \multicolumn{2}{|l}{} \\
\hline
\end{tabular}

\section{S ScholaroNE \\ Manuscript Central}




\section{Systems modelling and the development of coherent}

\section{understanding of cell biology}

\begin{abstract}
This article reports on educational design research concerning a learning and teaching strategy for cell biology in upper-secondary education introducing systems modelling as a key competence. The strategy consists of four modelling phases in which students subsequently develop models of free-living cells, a general 2-D model of cells, a 3-D model of plant cells and finally they are engaged in formal thinking by modelling life phenomena to a hierarchical systems model._The strategy was thought out, elaborated and tested in classrooms in several research cycles. Throughout the field-tests, research data were collected by means of classroom observations, interviews, audio-taped discussions, completed worksheets, written tests and questionnaires. Reflection on the research findings eventuated in reshaping and formalizing the learning and teaching strategy, which is presented here. The results show that although acquiring systems thinking competence at the metacognitive level needs more effort, our strategy contributed to improving learning outcomes, i.e. acquisition of a coherent conceptual understanding of cell biology and acquisition of initial systems thinking competence, with modelling being the key activity.
\end{abstract}

\section{Introduction}

A basic understanding of the functioning of the cell is essential for a sound understanding of the functioning of the multicellular organism. Therefore, students are taught a large variety of life structures and processes at the cellular level. The concepts used to describe these however, often remain fragmentary because they are mainly drawn from the sub-cellular level
Formatted: Font: 12 pt, Complex Script Font: $12 \mathrm{pt}$

\section{Deleted: भI}

Many students fail to acquire a coherent conceptual understanding of the cell as a basic unit of life. To address this problem we introduce systems thinking as a key competence. A main characteristic of systems thinking is distinguishing and linking the various levels of biological organization, i.e. molecules, cells, organs, and explaining life phenomena. To render phenomena that are either complex or not directly perceivable more readily visible, using models is an essential element of systems thinking at the cellular level. 
and not sufficiently integrated with concepts at the cellular and organism level. The latter explains why many students fail to acquire a coherent conceptual understanding of the cell as a basic unit of the organism (Dreyfus \& Jungwirth, 1988; 1989; Flores, Tovar \& Gallegos, 2003). In addition, conceptual problems associated with a lack of interrelating the levels of biological organization arise when studying other biological topics as well (Núñez \& Banet, 1997; Songer \& Mintzes, 1994). Songer \& Mintzes for example, refer to a problematic understanding of the relations between events of cellular respiration and various biological phenomena such as breathing, circulation and energy flow in natural ecosystems.

Douvdevany, Dreyfus \& Jungwirth (1997) showed that even the knowledge of junior high school teachers of cellular processes lacked coherence, although they had enough specific declarative knowledge of the cell. Interviews that we conducted with Dutch uppersecondary biology teachers, and content analysis of textbooks, revealed difficulties similar to those identified in the research papers mentioned (Verhoeff, 2003). In Dutch textbooks the cell has an important but very isolated place and is generally one of the first subjects dealt with in upper-secondary education. In addition, cell biology, as it is introduced in the school curriculum, mainly focuses on structures rather than on processes, although an understanding of biological processes has been recognised as being essential for a comprehensive understanding of biological systems (Chi, Slotta \& Leeuw 1994 ; Songer \& Mintzes, 1994; Barak, Sheva, Gorodetsky \& Gurion, 1999).

Our study is part of a research programme that focuses on the implementation of systems thinking in upper-secondary biology education. We concentrated on learning and teaching cell biology with the assumption that purposeful application of systems thinking provides a way to address the acquisition of coherent understanding of cell biology. In this approach, the

\begin{tabular}{l} 
Deleted: An example of this is \\
provided by \\
\hline Deleted: (1994) \\
Deleted: who
\end{tabular}

Formatted: Indent: First line: 21.3 pt Deleted:

Deleted: et al. 


\section{Design of the study}

Our developmental research approach (Lijnse, 1995) strongly resembles what Cobb, Confrey, DiSessa, Lehrer \& Schauble (2003) described as 'design experiments' conducted in a classroom setting. This approach implies the instructional design of a teaching and learning process, accompanied with a set of argued expectations of how the process is expected to take

development and use of models is crucial, so we introduced systems modelling as a key competence for students. This competence is defined here as the ability and willingness to link different levels of biological organization from the perspective that natural wholes, such as organisms, are complex and composite, consisting of many interacting parts, which may themselves be lesser wholes, such as cells in an organism (Mayr, 1997). The use of models is essential because in biology, structures and processes at different levels of biological organization are often abstracted into models. Especially at the molecular and cellular level, models are used to enable aspects of a system, which are either complex or not directly perceivable, to be rendered more readily visible. Moreover, models are potentially valuable learning and teaching tools for developing a scientific way of thinking (Gilbert, 1993).

Although the Dutch examination syllabus underlines the importance of systems thinking ${ }^{4}$ in biology education, the implementation in classroom practice falls short of expectations. Against this background, our overall research question was formulated as follows:

How can systems thinking, including modelling, enable students to develop a coherent understanding of the cell as a basic and functional unit of the organism?

This problem statement was the starting point of our developmental research project which entailed identifying the main criteria for designing an adequate learning and teaching strategy (LT-strategy), and optimising the strategy through cyclic empirical testing.
Formatted: Indent: First line: 21.3 pt

Formatted: Font: $12 \mathrm{pt}$, Complex Script Font: 12 pt

Deleted: et al. 
place and why it should operate according to the expectations (Bulte Westbroek, De Jong \& Pilot 2006). These expectations are based on the literature as well as on the results of previous research cycles. The learning and teaching process is optimised in several research cycles, focused on testing, reflecting on and adjusting the designed learning and teaching activities, in close co-operation with teachers. Testing the designed teaching and learning process takes place in a small-scale case study, with a classroom and its teacher as unit of analysis (Cobb, Stephan, McClain \& Gravemeijer, 2001). Eventually this cyclic research approach leads to an optimised domain specific learning and teaching theory, which prescribes what learning and teaching activities should be placed in what sequence in order to obtain an LT-strategy that enables students to attain the desired learning outcomes. Since the relation between the activities and outcomes is studied in detail, the domain specific theory also explains how the intended learning outcomes of the strategy have been attained.

In our study, we initially identified the general characteristics and structure of a preliminary LT-strategy assumed to be effective for cell biology from a systems theory perspective. This strategy was optimised in four subsequent case-studies at two different schools. These were carried out in form four (students aged 15-16) of pre-university education at two different schools ${ }^{1}$. These schools can be typified as rural schools with few students from ethnic minorities (2\% and $0 \%$ respectively; national level is $5 \%$ ). Both participating teachers were experienced biology teachers with more than 20 years of teaching experience.

During each case-study, the question was answered to what extent the implemented LTstrategy was in accordance with the expectations and the underlying theoretical framework. Evaluation of the implemented LT-strategy, gave rise to improvement of the strategy, which was field-tested in a next case study. This way, the feedback of practical experience into the

\footnotetext{
${ }^{1}$ Average number of students per case study was 18; the total number of students was 72 .
}

\begin{tabular}{l} 
Deleted: \\
Formatted: English U.K. \\
Formatted: English U.K. \\
Deleted: et al. \\
Deleted: \\
\hline
\end{tabular}

Deleted: et al 
Data collection and analysis

Within each case study, the implementation of the LT-strategy was accompanied by the collection of extensive data sets from multiple data sources during and in between the lessons on cell biology, i.e. classroom observations, audio-taped classroom and group discussions, completed worksheets, written tests and interviews with students and teachers (Verhoeff, 2003). All audio-tapes were transcribed verbatim. In analysing the data sets, the emphasis was on discourse analysis and reconstruction of the learning and teaching process by inspecting and comparing data from the different sources mentioned. Data collection and analysis was guided by the following two questions:

1) What learning outcomes arise from the implemented learning and teaching strategy, and what learning processes did these learning outcomes constitute of?

2) What indications can be derived from the observed learning processes and outcomes for revising the learning and teaching strategy?

Answering these questions led to revision and further elaboration of the LT-strategy, to be tested in the next case study. Therefore, each subsequent case study again addressed the above questions.

The observations made by the researcher in the classroom mainly focused on identifying ${ }^{+}$ critical moments regarding students' motivation and learning problems (expressed through content-related questions). These observations provided input for and were checked by interviews with the teacher and students. Together these made clear both the students' and teacher's perception of the learning and teaching processes that actually took place in the 
classroom, and they provided a first impression of the adequacy of the content and sequence of the learning and teaching activities. A more in-depth study of the actual learning and teaching processes was achieved by transcription and detailed analysis of all audiotapes, including the interviews. In the analysis, each learning and teaching activity was considered as a meaningful unit. Analysis started with the transcripts of the teacher's audiotape, which gave an overview of the complete learning and teaching activity, including the teacher's guidance to various students/student groups. Subsequently, the group-discussions were studied. The worksheets and written test were used to check or interpret the results of the above steps and gave more insight into the learning outcomes per activity.

\section{A theoretical underpinning of the learning and teaching strategy}

This paragraph aims to illuminate the process of designing a learning and teaching strategy from three theoretical perspectives. First, the problem posing approach is described, which constitutes our pedagogical perspective. Second, a systems theoretical perspective is presented to deal with the learning problems described in the introduction. Finally, we elaborate on the process of modelling and present the key elements of our designed modelling strategy.

\section{The pedagogic approach}

In order to actively engage students in their own learning process, we chose a problem posing approach, which involves students on a content-related basis (Klaassen, 1995; Lijnse \& Klaassen, 2003). This pedagogic approach is based on the idea that students start on common ground and continually have a sense of the direction in which the LT-strategy as a whole will take them (Klaassen, 1995). An essential element during such a process is that students have content-related motives for starting and continuing their learning process. These motives are 


\section{Systems thinking and cell biology}

The literature study on (cell) biology education showed some main difficulties regarding a coherent understanding of the cell, as has been outlined in the introduction. These could be typified as difficulties in interrelating different concepts at the cellular level and interrelating concepts at the cellular and organism level. Our LT-strategy aims to cope with these 
difficulties and in doing so, we suggest that intentional use of systems thinking is valuable. This means that systems thinking is not only considered as a tool for developing coherent cell biological knowledge, but it also constitutes a desired learning outcome of the LT-strategy. The main outcomes of the LT-strategy thus reflect a systems thinking competence with the major focus on the cellular level, i.e. students should be able to: 1) distinguish different levels of biological organization, i.e. cell, organ and organism, and match biological concepts to specific levels of biological organization; 2) interrelate the cell biology concepts at the cellular level of organization (which we also refer to as horizontal coherence); 3 ) interrelate the cell biology concepts with concepts at higher levels of organization (or vertical coherence).

To introduce systems thinking competence in cell biology education, we derived an Formatted: Indent: First line: 21.3 $\mathrm{pt}$ initial systems concept from the General System Theory (Von Bertalanffy, 1969).This General System Theory is based on generalizations of the basic functions of life, i.e. metabolism, growth and development, and responsiveness to environmental stimuli. It emphasises the hierarchical structure and open nature of biological systems (metabolism for example requires that a living system exchanges matter with its surroundings). In genetics education the General Systems Theory has been used earlier by Knippels (2003) to cope with the complex nature of genetics. Since we decided to use and explicitly introduce systems thinking as a tool for developing coherent cell biological knowledge, the question ought to be answered as to how to start the LT-strategy. Starting with an explicit introduction of systems thinking could facilitate the development of cell biological knowledge. It would, however, require a lot of effort since it implies the development of the abstract systems concept. Therefore, we decided to first focus on the acquisition of a basic notion of the cell and its organization, implicitly developed from a systems perspective. Subsequently the development 


\section{Models and modelling}

of the systems concept would be facilitated by referring to the acquired notion of the cell 'as a system' and furthering insight using a systems perspective.

To develop a basic notion of the cell, an essential idea in cell biology was used: the distinction between autonomous cells or unicellular organisms and functional cells that are part of a multicellular organism (Verhoeff, 2003; see appendix 1, LTA 1 and 2). Since characteristics of the General System Theory are generalizations of the basic functions of life, our LT-strategy started with free-living cells, which can be observed through a microscope (appendix 1, LTA 3 -6). Consequently, acquiring a systems concept started at the cellular level as well, followed by its application to other organizational levels. When students consider the cell both as an autonomous system and as a functional part of a larger whole (appendix 1, LTA 7-11), distinguishing the level of organelles (as functional parts of the cell) and organs (as structural organizations of functioning cells) would become logical (Dreyfus \& Jungwirth, 1980; Verhoeff, 2003). Finally, an adequate understanding of the cell as a functional unit requires a final step in the LT-strategy in which the different levels of biological organization are interrelated (appendix 1, LTA $12-15$ ).

University biology textbooks as well as textbooks used in secondary education contain many two- and three-dimensional models that focus on different aspects of cells. Therefore, it goes beyond saying that models are essential in an introductory course on cell biology. As argued in the introduction, the use of models is included in systems thinking, since models are very helpful in visualizing abstract concepts or theories. The question we focused on was how models can be used to optimize an LT-strategy that combines the introduction of systems thinking with development of coherent cell biological knowledge. 
In the last 15 years a considerable number of theoretical and empirical papers on the use of models and modelling in science education has been published, recognising the functionality of models in scientific thinking. For example, Gilbert (1993) considers models as integral to thinking and working scientifically because models are sciences' products, methods, and its major learning and teaching tools. Because of the large variety of models used in science and science education, typologies of models (as presented by Coll \& Taylor, 2005; Gilbert \& Boulter, 2000; Harrison \& Treagust, 2000) are helpful in characterizing selected models. An important dimension seems to be the distinction between idiosyncratic, mental models and analogical, scientifically accepted consensus models (Gilbert \& Boulter, op.cit.) or symbolic models (Harrison \& Treagust, op.cit.).

In cell biology we are dealing with expressed scale models (Harrison \& Treagust, op.cit.) depicting the structure, or an idealised structure, of cells. In systems thinking, theoretical models are the central point, since they are primarily derived from systems theory and not from (abstracted) biological phenomena. Accordingly, the systems thinking competence described in the previous section was expanded with a fourth (modelling) component (see table 1); i.e. students should be able to think back and forth between general system models and more concrete representations of cells, e.g. ranging from abstract cell models to real cells seen under a microscope.

\section{[Insert table 1 about here]}

Linked to our decision to start with an introduction to cell biology before explicitly addressing systems thinking, the LT-strategy should start with the development of scale models, and result in the development of a theoretical systems model. A trajectory for such a learning 


\section{The modelling strategy}

Figure 1 shows the modelling strategy towards acquiring coherent cell biological knowledge and systems thinking competence. It entails a succession of four modelling phases, preceded by a general orientation that poses the main steering question of the learning and teaching strategy and provides a general motive for studying the topic at hand (see appendix 1). Except for this first phase, all phases address the active engagement of students in the physical process of modelling, in which formation, revision and elaboration of cell models are performed respectively. In this process, thinking back and forth between the constructed 
models, real cells and expressed models of their learning materials, constitutes the fourth systems thinking competence (see table 1).

\section{[Insert figure 1 about here]}

The four modelling phases in our LT-strategy can be described as follows:

(M 1) Referential activity in which students develop models of free-living cells

(M 2) General activity in which students develop a general 2-D model of cells

(M 3) General activity in which students develop a general 3-D model of cells

(M 4) Formal thinking by modelling representations at the organism, organ and cellular level into a general systems model.

We decided to start the referential activity in phase M1 with the question whether students recognize the life functions of (familiar) organisms in free-living cells. A positive answer would make it plausible to start with modelling a general model of free-living cells before the general activity (phase M2) in which models of free-living cells, and models of plant and animal cells are transferred into one general cell model.

We assumed that the step from 2-D modelling (M-2) to 3-D modelling (M3) would enable students to more clearly visualize the relations between cell organelles. Support for this decision was found in the work of Al-Thuwaini (2003), who showed in his study on the use of virtual reality techniques for visualising abstract scientific concepts that 3-D visualizations strengthen students' understanding of cell biology concepts more than 2-D visual support does. The main advantage of 3-D representations seems to be that they present 


\section{Students' performance}

information in a manner that allows students to interact with phenomena as though in reality, more than 2-D representations do.

As appendix 1 shows, phase M4 was divided into two steps. M4a engaged students in exploring human digestion by modelling structures and processes at the level of the organism, organ and cell. The abstraction of structures and processes at each level showed that the three levels together can be represented by a general (hierarchical) systems model in which the initial cell model can be embedded. In order to widen the range of applicability of systems thinking, and to provide insight into the added value of the competence in subsequent learning, students applied the nested open-system model to another biological topic, i.e. breast-feeding (M4b).

The different levels of organization clearly structured the biological content-matter in the LT-strategy. The strategy started at the level of the organism in the preceding learning and teaching unit of growth and development, descended to the cellular level, addressed horizontal coherence and eventually related the cellular level to the organism level, i.e. ascended to the level of the organism and addressed vertical coherence. The strategy showed that sufficient knowledge of a biological topic such as cell biology is needed as a vehicle to develop a content-specific motive for systems thinking. Its application to several biological topics that transcend several levels of organization further proved the added value of the competence.

The four components of a systems thinking competence, as described above, provided evaluation criteria for testing the adequacy of the actual LT-strategy in four successive case studies. The first two case studies were considered as pilot studies providing a first insight 
into the key elements of our strategy as described in the previous section and appendix 1 (see also Verhoeff et al., 2003). The results presented here, are based on the third and fourth case study in which 28 students participated.

In general the nature and sequence of the learning activities constituting the four modelling phases of the tested LT-strategy could be considered adequate. The LT-strategy enabled students to explore the different functions of the cellular structures and complex interrelations within the cell based on concrete observations of real cells and different physically constructed cell models, resulting in an integrated view of the cell and its organelles. Hereby, the active engagement of students in the development of subsequent cell models guided them into the intended direction and improved students' insight into the (spatial and dynamic) organization of the cell (horizontal coherence). This started by developing a model of freeliving cells and applying it to the cell as a functional unit in phase M1 and M2 respectively. In the subsequent modelling phases M3 and M4 the main results of our LT-strategy, i.e. the acquisition of both a coherent conceptual understanding of cell biology and systems thinking competence, could be derived. Therefore the last two modelling phases are illustrated in this section by two key activities: building the 3-D large-scale model of a plant cell and applying the hierarchical systems model to a topic that transcends several levels of organization.

\section{M1: Developing a model of free-living cells}

Observation of free-living cells through the microscope proved a meaningful starting point for developing a general model for multi- and unicellular organisms. Students referred to the fundamental life processes as feeding or taking up nutrients (and using it for energy or as building material), breathing, growing, regeneration, excreting waste material and self- 


\section{$[3 ; 2 ; \mathrm{C} ; 1]^{2}$, T is teacher}

T: $\quad$ Why did Van Leeuwenhoek think that micro-organisms also had bowels like that of a large animal?

Ilona: He knew little about it.

T: $\quad$ Yes, but why then did he expect that they had bowels?

Elske: Because they could move.

T: $\quad$ And so...

Nienke: He just thought they were animals.

Elske: And therefore there must be energy, and so he must eat, and thus there should be...

T: $\quad$ Exactly, a combination of Elske's and your answer. They are animals, they can move so they probably have bowels. This in itself is a very logical train of thought. Eh, why can't they have bowels?

Ilona: Too small.

Elske: Composed of cells.

T: Yes, organs are composed of cells, so it's technically impossible. So, then the question is: how does a micro-organism do it? And that's really the question and therefore I leave it open to you. If a unicellular organism doesn't have bowels, how does he do it then? What should it have instead?

\footnotetext{
${ }^{2}$ Protocol fragments are indicated as [case study number; lesson; source; serial number of fragment]. Data sources are abbreviated as follows: $\mathrm{C}=$ whole class discussion, $\mathrm{G}=$ group discussion, e.g. [4; 6; $\mathrm{G} ; 3$ ] indicates the $3^{\text {th }}$ fragment in this article, which shows a group discussion during the $6^{\text {th }}$ lesson of the $4^{\text {th }}$ case study.
} 
The comparison between unicellular and multicellular organisms at a general level proved to be useful in distinguishing functional units, i.e. organs and organelles, and explicating their interrelations. At the end of phase M1 students had developed their model of free-living cells based on their observations of Paramecia through the microscope. There was a consensus that (1) cells have a membrane that enables input and output of materials, (2) cells contain organelles that fulfil specific functions for the cell and (3) the organelles are interrelated. Moreover, the intended question was raised by a student whether 'the characteristics displayed only apply to free-living cells or to our body cells as well?' This question provided the motive for investigating animal and plant cells at the beginning of phase M2.

\section{M2: Developing a general 2-D model of cells}

Formatted: Font: Italic

The next step in the LT-strategy was to explore the cell and its organelles and construct a general model of cells. This was achieved by applying their own model of free-living cells to cells that are part of an organism, and adjusting it when necessary.

Exploration of the cell as a functional unit, guided by their own constructed model in ${ }^{4}$ phase M1, seemed to be an obvious step to most students: 'Well, cells in our body are living units too, so they have to perform the fundamental life processes as well'. To the students' surprise, hardly any structures could be distinguished in the animal cells, and just a few in plant cells, when viewing them with a light microscope. During the class reflection the electron microscope was proposed as an useful alternative, providing a closer look at both animal and plant cells:

$[4 ; 4 ; \mathrm{C} ; 2], \mathrm{T}$ is teacher

T: $\quad$ Who has seen cells with organelles? 
Elly: I haven't.

Mark: Of course you have.

T: $\quad$ Everyone, isn't it?

Ankie: Yes, I think I've seen them.

Sarike: $\quad .$. But there weren't many inside.

T: It is less clear than you hoped for, and less clear than in the model. And now the big question is: Is that due to the model? Isn't the model right, don't cells consist of that (points to the organelles in the model on the blackboard)? Or is it something else? Should we doubt the model or the cells? Who has an explanation?

Birgit: I think they're too small to see under this microscope.

T: $\quad$ So, if you would have another microscope, with a higher magnification, you would be able to see those organelles?

Birgit: Yes, because even in the red onion you couldn't see the nucleus.

T: Whereas it is a huge cell.

Birgit: Yes.

T: $\quad$ Those chloroplasts, being organelles, could be easily seen in all kinds of cells. In the cheek cells you could see some dots, but not much more. So, this is already a very scientific way of reasoning, isn't it? You stick to your model until it turns out to be otherwise, which seems to be the case now. But then you could still say: well maybe the model is right after all, but I just need better equipment (...).

Studying the electron microscopic photos brought on some unexpected reactions at first. Instead of being struck by the enormous complexity of the cells, students were surprised by the fact that the 'standard structure' of the cell with the organelles, cell wall and nucleus was clearly visible. The fact that students 'saw' the structure as depicted in their general model can be ascribed to students' interpretations of the pictures. They only took the clear round shapes (mitochondria and chloroplasts) for being organelles. The majority of the students needed some help of the teacher to realise that the cell structure was more complex than they had assumed at first sight. In these cases the teacher stimulated students to not only focus on 
the round structures, but also on differently shaped structures. Students then concluded that 'in fact almost everything is an organelle!' realising that the number of (different) organelles in the cell was larger than they had expected.

The complexity of the electron microscope photos brought on the need for a cell model, providing a clear picture of the cell and its organelles. The model was introduced in a short text as the result of the comparison between an enormous variety of plant cells and as an orderly representation of the general and structural characteristics. By comparing the photos with an orderly cell model as depicted in their workbooks, students could further explore the cell and its organelles. For example, the mitochondria, Golgi-apparatus and nucleus were directly recognised and labelled. At the end of this phase, reflection on the use of modelling in acquiring a coherent understanding of the cell revealed that students realised the potential of using models in labelling the organelles and reducing the complexity visible on the electron microscope photos.

\section{M3: Developing a 3-D model of a plant cell}

In the first two modelling phases, students developed a model of free-living cells and applied it to the cell as part of a multicellular organism. During the LT-activities in these phases students had come across various cell models, ranging from their own drawings to the developed (general) cell model, and models of free-living, animal and plant cells. In phase M3 students were subdivided in groups, and each group constructed (and presented) a 3-D model of a certain cell organelle which was to be placed in a large 3-D cell model. In doing so, students used different models represented in their textbook, other biology books and on the Internet. Some student groups, for example, used dynamic computer models to explain the functioning of a specific organelle. In order to construct a 'consensus' 3-D model of the cell,
Formatted: Indent: First line: 21.3 pt

Formatted: Font: $12 \mathrm{pt}$, Complex Script Font: 12 pt 


\section{[Insert figure 3 about here]}

The activity of building a cell model also addressed the horizontal coherence at the cellular level, as students were actively finding relations between the organelles. From schematic pictures of cells and pieces of text in their book, students got some first clues about which organelles were related. Patricia and Renske, two students who studied the endoplasmatic reticulum, realised that it was related to the nucleus. Immediately the next question came up: 'Okay, here is the nucleus on this picture but, and that's still a problem for us, how are 'we' connected to the nucleus?' Subsequently, they turned to the students who studied the nucleus and asked them how their organelles were related. After the conversation, Patricia decided that 'the nucleus sends RNA to us ... so that we can make these eh proteins with our ribosomes ... So the connection is that they make RNA for our ribosomes'. At that moment she correctly stated that ribosomes are made of RNA. However, this brought up another problem that she presented to the teacher:

$[3 ; 6 ; \mathrm{G} ; 3]$

Patricia: Does the nucleus produce ribosomes or does it send RNA to us, so that we can make ribosomes? [...] Because I couldn't find where ribosomes are made. 
Teacher: That's a point! Ribosomes are assembled outside the nucleus. Not by the ER, but it certainly happens somehow, I don't know.

Patricia: There has to be a connection with the nucleus, since we need ribosomes.

Teacher: Yes, and the RNA of which these ribosomes are made.

Patricia: Yes.

Teacher: You receive it from the nucleus indeed, and to be exact you receive it from the nucleolus.

Patricia: Yes. Because in the nucleolus... so we need RNA, so that we have ribosomes, that contain protein molecules so that we..

Teacher: Produce! They contain....yeah, they also contain...

Patricia: Do they produce them also?

Teacher: They do, that's the point. They produce proteins.

Patricia: Oh, the book says 'contains'.

Teacher: Yes, that's right in a way, but they produce proteins; that's what it's about.

Patricia: And by doing so, the rough ER can make proteins and the smooth ER makes glycoproteins out of that.

The discourse fragment illustrates that students were actively trying to grasp the nature and functions of the interrelations between the organelles. Students explicitly helped each other in gathering information on the relations between the organelles. Sometimes this cooperation became a kind of role-play in which students identified themselves with their organelle.

At the end of the tenth LT activity (see appendix I), most students were able to interrelate the different organelles, in terms of describing the exchange of matter and information and connect them to cellular processes as could be concluded from their plenary presentations (learning activity 11). Moreover, the presentations brought on discussions during which students tried to attain a better understanding of the nature of the relations between the organelles. The next fragment illustrates this. It follows a presentation during which Elske puts forward the dynamic nature of the Golgi apparatus and deals with the continuity of the absorption and formation of vesicles by the Golgi: 
[3; 7; C; 4]

Jerry: Does it move itself each time from the cell membrane to, in the direction of the nucleus, or in the direction of the rough $\mathrm{ER}$, because it extends to the other side as a result of the vesicles that are added? And on the other side, each time they go...

Nienke: No, but the vesicles come from the ER, then go to the Golgi-system and are transported further. On the other side of the Golgi, the membrane is used for further transportation.

Jerry: $\quad$ So, on one side membrane is added and...

Elske: Yes, but on the other side membranes are separated, they pinch off.

Teacher: So it stays at the same place.

Elske: Yes, on one side it adds on and on the other side it goes off.

Jerry: $\quad \mathrm{O}$, the membrane travels completely through it.

Elske: $\quad \mathrm{O}$ yes, the pieces of membrane themselves, they travel through the entire cell, that's right.

Eric: But also through the entire Golgi-system.

Teacher: Yes, you must realise that when you observe the ER and how it looks now, the same applies for the Golgi apparatus. Look at them ten seconds later and it is entirely different. It's disappointing about your model: that you didn't bring that into it. Still, it's an incredibly flexible whole.

Patricia: Our model is flexible alright!

Teacher: Take a look a few minutes later and its shape is totally different. There are vesicles coming and going, etcetera. Actually, it is not possible to make that; it is already difficult to make it in three dimensions. As a matter of fact there is also a fourth dimension because you could bring the time dimension into it. Well that's not possible to do, but in a few seconds the cell looks totally different.

The above discussion illustrates the dynamic picture of the cell that emerged in the plenary discussions, including the interrelations between the organelles. The dynamic character of the cell was apparent in the majority of the student presentations. For example, the cell membrane was explained with the help of an animation of the transport processes that students had found on the Internet. 
M4: Modelling representations at the organism, organ and cellular level to a general systems model

The fourth modelling phase dealt with the introduction and explication of an hierarchical systems model. So far, the structural parts and their interrelations had been studied at the cellular level, and now the organ and organism level were added by means of a computeraided programme. This programme enabled students to explore the processes of human digestion from the cellular level up to the organism level by different exercices, e.g dragging and dropping organs at the right place in the body, drawing arrows to indicate exchange of matter/information between cells. At each level, the structures and processes were formalised into the same systems model. At the cellular level students immediately recognized the general cell model developed during M3, and no difficulties were experienced in connection to the formalization at the level of the organ and organism. This led to our conclusion that the hierarchical systems model was introduced in a way that was meaningful to students. Moreover, the final assignment of the computer-aided programme that addressed the integration of the models at the different levels of organisation, was completed by all students engaged in the assignment. During this written assignment, students were asked to draw a hierarchical systems model of the organism by combining the models at the cellular, organ and organism level (see also Verhoeff, 2003).

Subsequently, students applied the hierarchical open-system model to a biological topic manifesting itself at different levels of biological organization, i.e. breast-feeding (see figure 4). In applying the systems model to this topic, students had to interpret the representations of the process of breast-feeding by fairly realistic models, and think back and forth between those models and the more general hierarchical systems model. This process seemed to
Deleted: II 


\section{[Insert figure 4 about here]}

Students were able to transfer their knowledge on the in- and output of the breast (hormones and milk respectively) to the mammary gland cells and subsequently linked the different organelles to the production of milk, starting with the nucleus 'receiving the hormone and, say, translating the message':

\section{$[3 ; 9 ; \mathrm{G} ; 5]$}

Elske: From the nucleus it goes to the rough ER, because that's what we heard during the presentation about the ER and then it goes to the Golgi and then to the mitochondrion.

Eric: But where does the milk come from, from what part of the cell?

Lisa: From the food vacuole.

Nienke: From the mitochondrion.

Lisa: O no, it comes from the membrane.

Nienke: Yes, but that's not one of the options! 


\author{
$[\ldots]$ \\ Lisa: Production of proteins takes place and subsequently they're passed on to the Golgi apparatus. Hey! So, \\ it goes from the ER to the Golgi apparatus! \\ Elske: Yes, but from the ER it goes to the Golgi apparatus and from the Golgi apparatus it goes to the \\ mitochondria. But, in my opinion, there isn't any milk coming from the mitochondria!
}

This last activity also enabled the teacher to identify misconceptions or gaps in students' understanding in terms of horizontal or vertical coherence, and thus address these problems. For example, in the above fragment students link the production of milk to the production of proteins in the ER and the subsequent transport to the Golgi apparatus as intended (see also figure 4). However, there is uncertainty about the remaining pathway leading to excretion of the milk, mainly caused by the uncertainty about the role of the mitochondrion. For discovering the vesicular transport route in the cell and linking the input of hormones to the output of milk, it was essential for students to realise that the Golgi apparatus excretes the milk. To this end, the teacher referred students to the schematic picture of a mammary gland cell. Students realised that the Golgi apparatus produced the milk and from there the students were able to reconstruct the vesicular transport pathway, starting with hormones entering the nucleus.

With respect to the interrelation of the different levels of organization, the teacher's Formatted: Indent: First line: 21.3 pt guidance was essential. At this point the systems model was not self-explanatory. Thus, although the assignment stimulated students to think about the relationships at the different levels of organization, it did not stimulate students to think back and forth between different levels. As a result, students were for example not able to develop on their own a complete and coherent systems model of the process in the breast. For this purpose, the supporting role of 
[4; 9; G; 6]

Teacher: Okay impulses arrive at the nerve cells here. What do these nerve cells do with it? [...] Try to go back to this (organism) level. Where do they have to go, these impulses?

Tim: To the mammary gland?

Marc Nerves.

Teacher: This is the mammary gland (points at the students' systems model). Two things left the mammary gland $[\ldots]$ subsequently it gave off impulses to the central nervous system.

Marc: Yes.

Teacher: If this is a nerve cell, then it passes on impulses to the pituitary gland. The pituitary gland produces hormones.

$[\ldots]$

Teacher: What comes into the breast, a few moments later?

Marc: These hormones.

Teacher: Hormones. Hormones are always in the...?

Tim: Blood.

Teacher: So, these hormones go to a blood vessel and from there they can ...

Tim: Muscles!

Teacher: Influence the muscles, indeed.

Tim: $\quad$ And the mammary gland.

Teacher: They can also go directly to the mammary gland. And those muscles, when they contract and there is a group of mammary glands in between.

Marc: Then milk comes out there.

Teacher: Yes. Okay, now you're going to explore the mammary gland cell further for a while.

As the above fragment demonstrates, the teacher helped students in thinking back and forth between the level of the mother and the breast. In doing so, he strongly steered the students 
into the desired direction. In addition, thinking back and forth between the different levels of organization was not reflected on in a classroom discussion as intended. Nevertheless, the discussions between the students eventually resulted in completed systems models after the teacher helped them to commence. Therefore, the problems described in science education literature, which are related to a lack of vertical coherence in students' understanding of biological phenomena, could basically be considered as having been tackled. Figure 4 shows a completed systems model at the three levels of organization that students had accomplished during learning activity 15.

In the final test, we asked students to depict at three organizational levels the stress Formatted: Indent: First line: 21.3 pt mechanisms in the human body described in a text. The majority of the students spontaneously used the hierarchical systems model during this test. The same was observed during some interviews one month later when students were asked to explain a (self-selected) biological topic manifesting itself at various levels of organization. Moreover, the test showed that most students were able to distinguish and label the cellular and organism level, including the constituent parts with their input and output and their interrelations, using the text on the specific topic. The majority of the students had difficulties with the level of the organ, although the systems thinking competence of a considerable minority of students encompassed the organ level as well.

\section{Discussion}

This study indicates how systems modelling can be introduced in upper secondary education, and supports our assumption that it enables students to acquire a coherent understanding of biological phenomena. More specifically, it provides an adequate solution to our problem statement that focused on how to integrate and explicate systems modelling in an LT-strategy 


\section{Highlights of the strategy}

In designing an LT-strategy that actively engages students in systems modelling, an important issue dealt with the nature of the intermediate models: should the students' learning process be based on (scientific) representations created by others or should they generate their own, perhaps less accurate, representations? As depicted in figure 1, our strategy integrated the use of microscope images of real cells with existing representations in (text) books and their own developed representations in testing, building and applying successive systems models of the cell. In the first phase (M1), the cell was meaningfully introduced as an autonomous, functioning unit, which provided a basis for students to generate their own (cellular) representations. These representations guided students' observations of animal and plant cells in phase M2. Moreover, thinking back and forth between this representation, real cells and cell models expressed in their textbooks provided a solid basis for developing an initial 2-D systems model of cells. This model expressed students' prior knowledge of cells, broadened with the representations of the organelles and their interrelations, in other words: the horizontal coherence in students' cell biological knowledge. The third modelling phase 
subsequently established a collaborative modelling activity during which students expanded their understanding of the dynamics and complexity of these interrelations, and resulted in a 3-D consensus model of living cells. In the final phase (M4), a computer-aided programme initiated the process of thinking back and forth between concrete representations and an abstract systems model of a biological topic. For students to grasp the additional value of this activity, the application of the hierarchical systems model to a biological topic covering the different levels of biological organization proved to be essential. In this phase the hierarchical systems model emerged as a tool for exploring biological phenomena both horizontally and vertically.

\section{Systems modelling at the metacognitive level}

The process of modelling engaged students in the scientific practice of using models as tools for observation, exploration, synthesis and, to a lesser extent, prediction of biological systems and their behaviour. Thus, developing systems models not only has the potential to help students to learn about biological systems, it can also foster their understanding of the nature of science as an enterprise that is largely concerned with extending and refining (systems) models (Gilbert, Boulter \& Rutherford, 1998). In doing so, it seems worthwhile to engage students in informed and purposeful modelling activities, to the extent that they have command of the process of modelling and become aware of how modelling promotes understanding of complex biological phenomena. These notions imply metacognition, which is fundamental to purposeful inquiry, i.e. asking oneself specific evaluative questions (reflecting) and implementing procedures to gain answers to these questions (acting) (Baird \& White, 1996; De Vries, 2004).
Formatted: Font: $12 \mathrm{pt}$, Complex Script Font: $12 \mathrm{pt}$

Deleted: et al. 
Our study implicates that the introduction of systems thinking provides a meta-cognitive ${ }^{+}$ tool for dealing with the study of biological topics that follow after an introductory course on cell biology. To this aim, we used the systems thinking competence derived from the General Systems Theory to order the biological content-matter. Moreover, we used systems thinking to address both horizontal coherence in terms of structures and processes at specific levels of organization and vertical coherence between these structures and processes at different levels of organization. The 3-D modelling phase (M3) demonstrated advantages for understanding complex phenomena or abstract scientific content, and enables students to visualise concepts which could otherwise remain esoteric (cf. Al-Thuwaini, 2003). The acquisition of a systems thinking competence at the metacognitive level, which was one of the main objectives of our study, was a central aim of the final modelling phase. In this phase, the hierarchical systems model introduced within the context of cell biology was explicitly utilized in relating cellular structures and processes to higher levels of organization.

The results of our strategy showed that each modelling phase could indeed be recognized by students as worthwhile in further exploring the complex interrelations within the cell and the coherence between cells and the organism. However, the claim that our LT strategy would result in the desired systems thinking competence has not been justified. In this respect, the importance of the teacher's guidance in the last activity, e.g. stimulating students to think back and forth between the different levels of organization, was indicative. Evidently, acquisition of systems thinking requires more effort than one series of lessons. The systems model should be explicitly used when other biological topics such as evolution, behaviour and metabolism are dealt with. These topics have in common the integration of knowledge of processes and structures at several levels of biological organization. 
Accepting systems thinking as a major competence for upper secondary biology students obviously has implications for the content and structure of the biology curriculum. Biological systems studied in the biology curriculum are open hierarchical systems; therefore all biology topics could be approached from a systems theoretical perspective derived from the General System Theory. For example, the molecular biology of any topic could be introduced by extending the hierarchical systems model to the molecular level. At this additional level of organization, molecules can also be seen as interrelated parts that have a function within the system that they are part of (organelle or cell). The only prerequisite for a systems approach seems to be that topics are defined in such a way that they cover different levels of biological organization. Several topics in the Dutch biology curriculum in upper secondary school such as cell biology, behaviour and ecology, are defined in such a way that they are limited to only one level of biological organization, or they do not include the organism level that is closest to students' experiences. Therefore, redefinition of curriculum topics could be worthwhile.

\section{References}

Formatted: Font: $12 \mathrm{pt}$, Complex

Abell, S.K., \& Roth, M. (1995). Reflections on a fifth-grade life science lesson: Making sense of children's understanding of scientific models. International Journal of Science Education, 17, 59-74.

Al-Thuwaini, S.E. (2003). Visualising abstract scientific concepts by virtual reality. Studies on using virtual reality techniques in Kuwait education. Enschede: Universiteit of Twente.

Baird, J.R., \& White, R.T. (1996). Metacognitive strategies in the classroom. In: Treagust, D.F., Duit, R. \& Fraser, B.J. (Eds.) Improving teaching and learning in science and mathematics (pp.190-200). New York \& London: Teachers College Press. 
Barak, J., Sheva, B., Gorodetsky, M., \& Gurion, B. (1999). As 'process' as it can get: students' understanding of biological processes. International Journal of Science Education, 21 (12), 1281-1292.

Bulte, A.M.W, Westbroek, H.B., De Jong, O. \& Pilot, A. (2006). A research approach to designing chemistry education using authentic practices as contexts. International Journal of Science Education, 28 (9), 1063-1086.

Chi, M.T.H., Slotta, J.D., \& Leeuw, N.D. (1994). From things to processes: a theory for conceptual change for learning science concepts. Learning and Instruction, 4, 27-43.

Clement J., (2000). Model based learning as a key research area for science education. International Journal of Science Education, 22 (9), 1041-1053.

Cobb, P., Stephan, M., McClain, K., \& Gravemeijer, K. (2001). Participating in classroom mathemathical practices. Journal of the Learning Sciences, 10 (1\&2), 113-163.

Cobb, P., Confrey, J., DiSessa, A., Lehrer, R., \& Schauble, L. (2003). Design experiments in educational research. Educational Researcher, 32 (1), 9-13.

Coll, R.K. \& Taylor, I. (2005). The role of models and analogies in science education. International Journal of Science Education, 27, 183-198.

De Vries, B. (2004). Opportunities for Reflection. E-mail and the web in the primary classroom. Thesis Universiteit Twente.

Douvdevany, O., A. Dreyfus, \& E. Jungwirth (1997). Diagnostic instruments for determining junior high-school science teacher's understanding of functional relationships within the 'living cell'. International Journal of Science Education, 19 (5), 593-606.

Dreyfus, A. \& Jungwirth, E. (1988). The cell concept of $10^{\text {th }}$ graders: curricular expectations and reality. International Journal of Science Education, 10 (2), 221-229. 
Dreyfus, A. \& Jungwirth, E. (1989). The pupil and the living cell; a taxonomy of dysfunctional ideas about an abstract idea. Journal of Biological Education, 23 (1), 4955.

Flores, F., Tovar, M.E. \& Gallegos, L. (2003). Representation of the cell and its processes in high school students: an integrated view. International Journal of Science Education, 25 (2), 269-286.

Ghesquière, P. \& Staessens, K. (1999). Qualitative casestudies. In: Levering, B. \& Smeyers, P. (eds.). Learning to see upbringing and education. An introduction to interpretative research. Amsterdam: Boom, 192-213.

Gilbert, J. (1993). Models and modelling in science education. Hatfield, Herts: Association of Science Education.

Gilbert, J.K., Boulter, C. \& Rutherford, M. (1998). Models in explanations, Part 1: horses for courses? International Journal of Science Education, 20, 83-97.

Gilbert, J. \& Boulter, C. (eds.) (2000). Developing Models in Science Education. Dordrecht: Kluwer.

Gravemeijer, K. (1999). How Emergent Models May Foster the Constitution of Formal Mathematics. Mathematical Thinking and Learning, 1 (2), 155-177.

Harrison, A.G. \& Treagust, D.F. (2000). A typology of school science models. International Journal of Science Education, 22, 1011-1026.

Janssen, F.J.J.M. (1999). Learning by designing in biology education. Worked out, tried and tested for immunology in secondary education. Utrecht: CDß-Press.

Klaassen, C.J.W.M. (1995). A problem-posing approach to teaching the topic of radioactivity. Utrecht: CD- $\beta$ Press. 
Knippels, M.C.P.J. (2002). Coping with the abstract and complex nature of genetics in biology education. The yo-yo learning and teaching strategy. Utrecht: CD-ß Press.

Lijnse, P.L. (1995). "Developmental research" as a way to an empirically based "didactical structure" of science. Science Education, 79 (2), 189-199.

Lijnse, P.L. \& Klaassen, K. (2003). Didactical structures as an outcome of research on teaching-learning sequences? International Journal of Science Education, 26 (5), 537554.

Mayr, E. (1997) This is biology. The science of the living world. Cambridge, Massachusetts/ London: The Belknap Press of Havard University Press.

Núñez, F. \& Banet, E. (1997). Students' conceptual patterns of human nutrition. International Journal of Science Education, 19 (5), 509-526.

Songer, C.J. \& Mintzes, J.J.(1994). Understanding cellular respiration: an analysis of conceptual change in college biology. Journal of Research in Science Teaching, 31, 621637.

Verhoeff, R.P. (2003). Towards systems thinking in cell biology education. Utrecht: CD- $\beta$ Press.

Verhoeff, R.P., Waarlo, A.J. \& Boersma, K.Th. (2003). Learning and teaching cell biology from a systems perspective - an interim report of a developmental research project. In: Proceedings of the fourth Conference of European researchers in Didactics of Biology $(E R I D O B)$, Toulouse, France, October $22^{\text {nd }}-26^{\text {th }} 2002$.

Von Bertalanffy, L. (1968). General system theory; foundations, development, applications. New York: George Braziller. 
How do free-living cells carry out the fundamental life processes?
Appendix 1: outline of the final learning and teaching strategy addressing systems modelling and the development of coherent cell biological knowledge
To what extent are our body cells different from freeliving cells? (main question) \begin{tabular}{l|l} 
Sequence of & Sequence of learning and teaching activities (LTA's) including time
\end{tabular} General orientation on cell biology

LTA 1: Brainstorming in groups (15 min). Bringing up prior knowledge about cells that is mainly related to the domain of growth and development.

- Students raise questions and wonder if their knowledge about cells applies to all cells.

LTA 2: Class discussion (25 min) directed by the teacher. Introducing and orientating on the cell as a basic unit of the organism within the context of growth and development, which raises students' interest in the following problem: All organisms develop from a single cell by cell division. At some point cells specialise: Would these cells still be able to survive outside our body just as free-living cells can?

-Students wonder what processes cells must carry out to maintain themselves and how they do this, leading to an interest in (autonomous) free-living cells.

M1 Developing a model of free-living cells

LTA 3: Group work (20 min). Reading a text about the smallest known 'freeliving' cell (Mycoplasma genitalium), discussing the application of the fundamental life processes to free-living cells and drawing an idiosyncratic representation of the cell as an organism.

-Students realise that the fundamental life processes apply to free-living cells, but wonder how they fulfil them.

LTA 4: Microscope practical and reflection (30 $\mathrm{min})$ on the process of thinking back and forth between their own developed model and observations of real cells. Investigating real free-living cells (amongst others Paramecium) guided by students' idiosyncratic representations of unicellular organisms and comparing their observations to their representations.

-Students understand that free-living cells have a general structure in which functional parts can be distinguished. They can describe the developed model as representing the fundamental life processes of unicellular organisms.

LTA 5: Group work on a written assignment (40 $\mathrm{min})$. Exploring the functions of the organelles within the context of nutrition, resulting in a (final) general model of free-living cells.

- Students understand that interaction between the (functional) organelles in free-living cells is essential to fulfilling the life processes.

LTA 6: Class discussion (20 $\mathrm{min}$ ) directed by the teacher. Reflection on the general model of free-living cells, including the process of modelling so far, and raising interest in cells as part of an organism.

- Students appreciate the model based on free-living cells as a tool for addressing the question: Do our body cells possess interrelated functional parts, i.e. organelles, as well? 
To what extent did the process of modelling help us in answering the main question (CQ)?

In what way are cells and the body as a whole mutually dependent?

How are multicellular

organisms organised?

LTA 13: Computer-aided programme in pairs $(20 \mathrm{~min})$. Exploring the The of endocrine regulation at the level of the organism, organ and cell.

- Students realise that the cell model also applies to cells and organs in an organism, and get a clear picture of how the body is organised.

LTA 14: Plenary reflection (10 $\mathrm{min})$ on LTA 13 . Explicating the levels of organization and the general characteristics of living systems. Explicitly 
answering the main question in terms of the cell being a functional system within the system at a higher level of organization.

- Students understand the hierarchical structure of the body and the general system characteristics, which apply to organisms, organs and cells.

What is the added value of the systems model?
M4(b) Application of the systems model

LTA 15: Group work and plenary reflection on systems thinking (40 min). Applying the systems model and interrelating the different levels of organization within the context of a specific biological topic (a nursing mother).

- Students view the systems model as a tool for explaining and acquiring a coherent understanding of a biological topic at different levels of organization and recognise the benefits of thinking back and forth between the different levels of organization. 
Table 1: Four elements of a systems thinking competence for cell biology education

Being able to distinguish between the different levels of organization, i.e. cell, organ and organism, and to match biological concepts with specific levels of biological organization. Being able to interrelate concepts at the cellular level of organization (horizontal coherence). Being able to link cell biology concepts to concepts at higher levels of organization (vertical coherence).

Being able to think back and forth between cell representations ranging from abstract cell models to real cells seen under a microscope. 


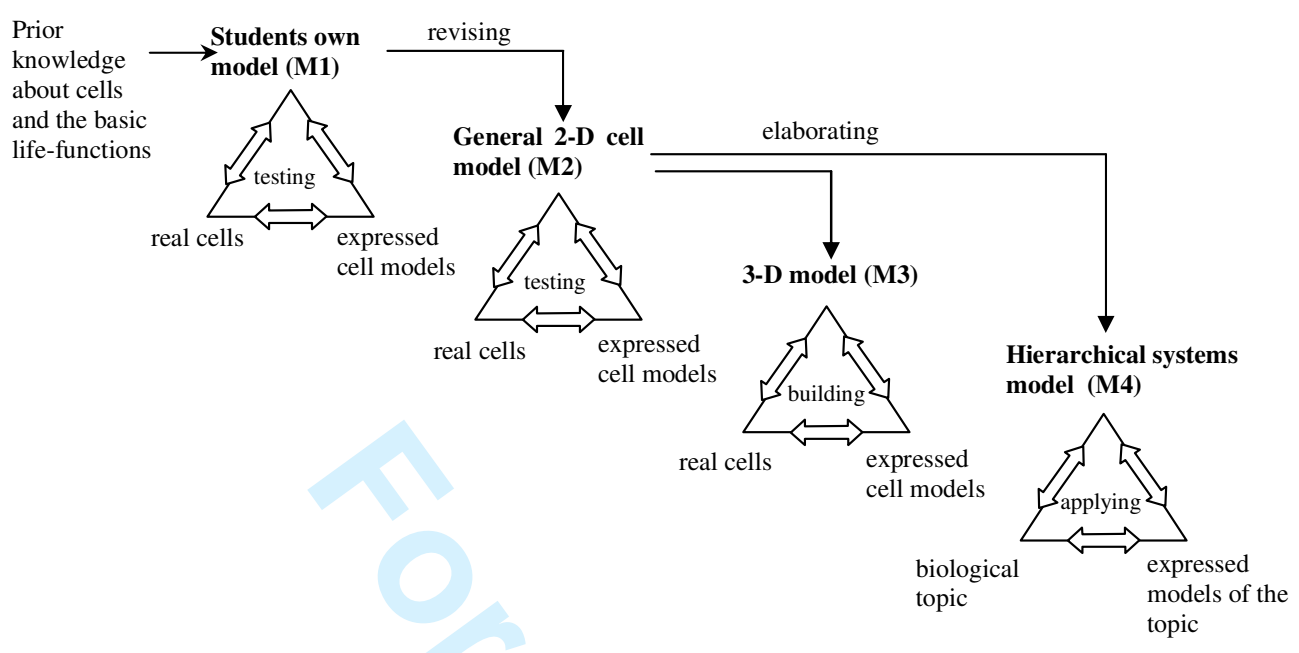

Figure 1: The learning trajectory from students' prior knowledge to the hierarchical systems model via intermediate models. 

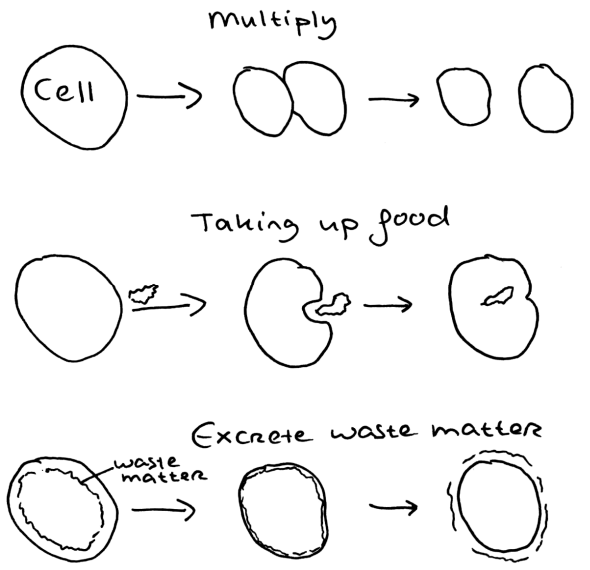

Figure 2: A student drawing of fundamental life processes fulfilled by a free-living cell 

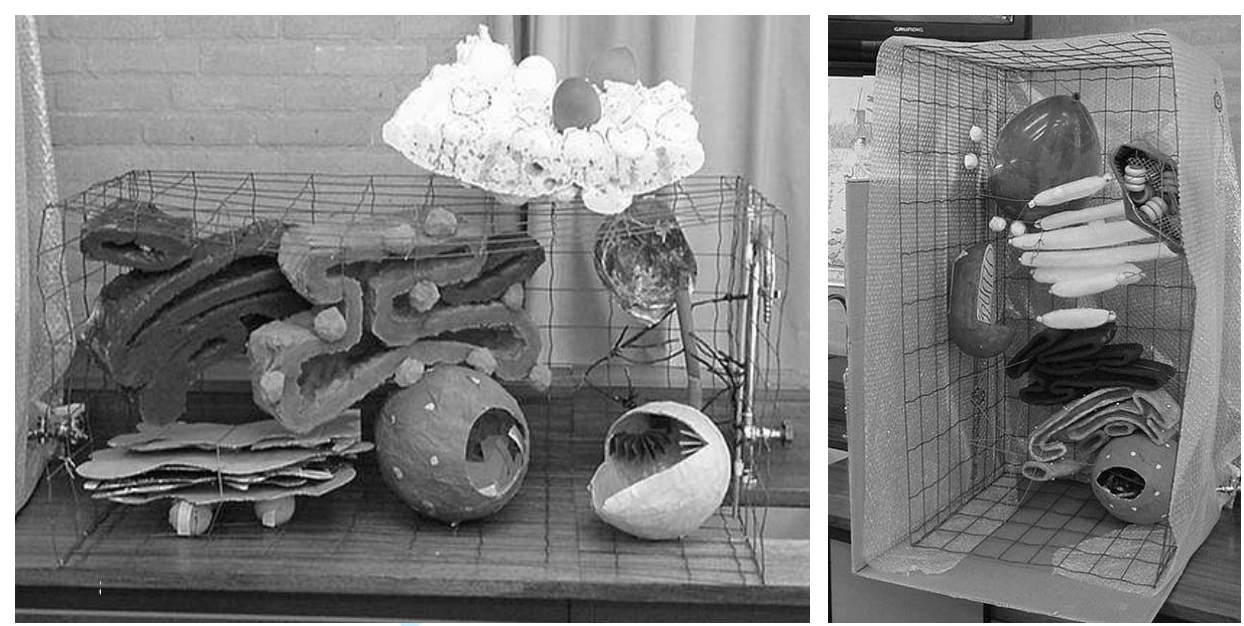

Figure 3: 3-D cell models constructed by students in a frame of $1 / 2$ by $1 / 2$ by 1 meter. The model includes the nucleus, endoplasmic reticulum (with ribosomes attached to it), Golgi apparatus (with lysosomes), cell membrane, chloroplast, mitochondrion and a vacuole. 


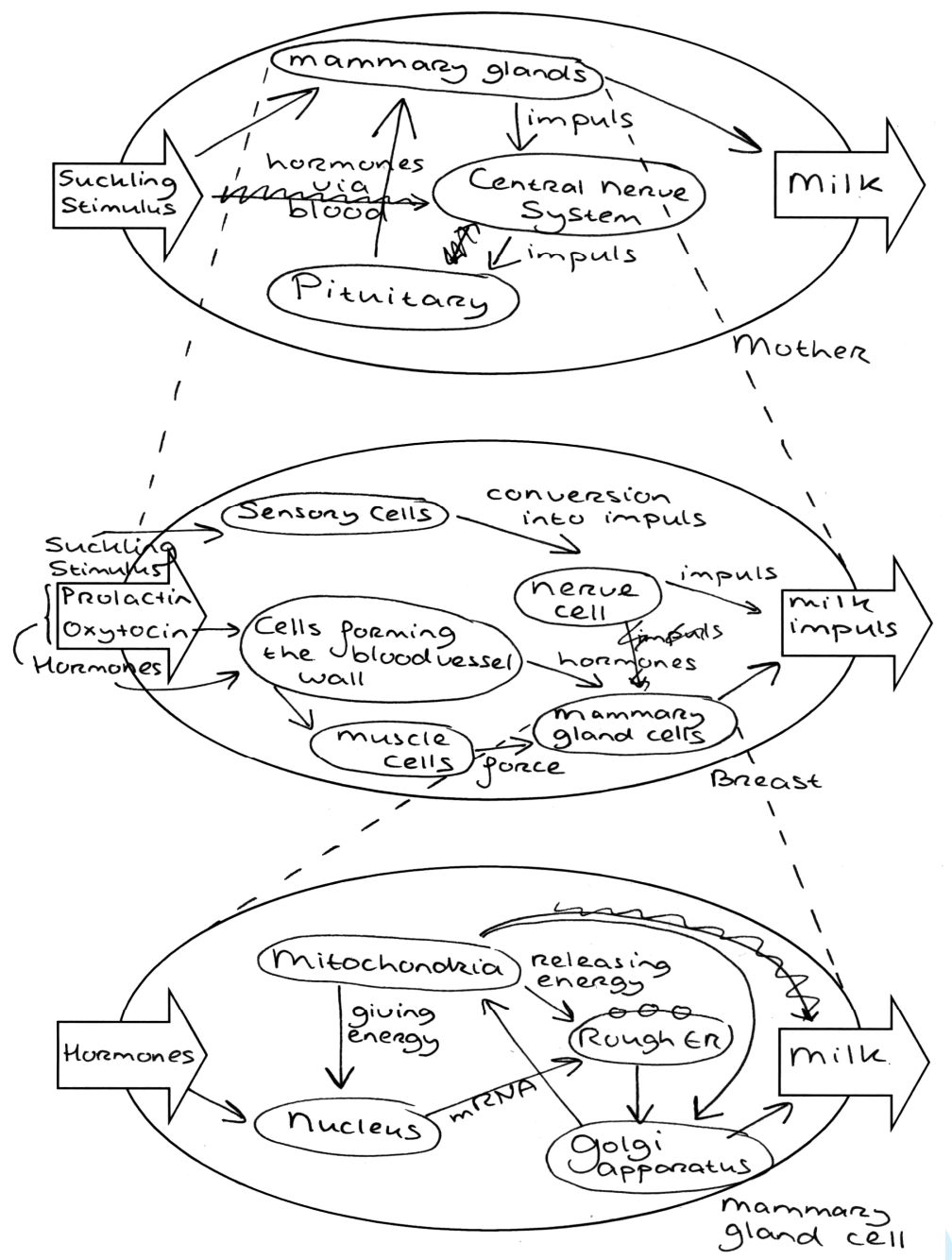

Figure 4: Students' completed systems model of breast-feeding, comprising of the organism- (top), organ- and cellular level. The teacher's help in constructing the model is illustrated at the cellular level: students initially depicted an arrow indicating that energy produced by mitochondria is directly released into the milk. 